\title{
Erratum to: Preliminary Application of X-ray Computed Tomography on Characterisation of Polish Gas Shale Mechanical Properties
}

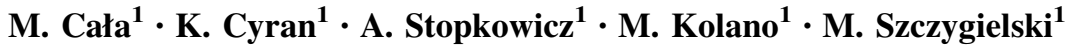

Published online: 19 October 2016

(c) Springer-Verlag Wien 2016

\section{Erratum to: Rock Mech Rock Eng \\ DOI 10.1007/s00603-016-1045-6}

In the original article the word "tomography" was accidentally replaced by the word "tomograph" during the proofreading and production process.

The online version of the original article can be found under doi:10.1007/s00603-016-1045-6.

\footnotetext{
K. Cyran

kcyran@agh.edu.pl

1 AGH University of Science and Technology, Aleja

Mickiewicza 30, 30-059 Cracow, Poland
} 